\title{
The Influence of Post Conflict Intervention Measures on the Reconstruction of Public Primary Teacher Training Colleges in South Sudan
}

\author{
Peter Ador Riak Nyiel $^{1}$, Daniel Komo Gakunga ${ }^{2} \&$ Rosemary Khitieyi Imonje ${ }^{1}$ \\ ${ }^{1}$ Department of Educational Administration and Planning, University of Nairobi, Nairobi, Kenya \\ ${ }^{2}$ Department of Educational Foundations, University of Nairobi, Nairobi, Kenya \\ Correspondence: Peter Ador Riak Nyiel, Department of Educational Administration and Planning, University of \\ Nairobi, Nairobi, Kenya.
}

Received: October 23, 2020

Accepted: February 23, 2021

Online Published: March 4, 2021

doi:10.20849/jed.v5i1.865

URL: https://doi.org/10.20849/jed.v5i1.865

\begin{abstract}
This study assessed the influence of humanitarian assistance post conflict intervention measures on reconstruction of public teacher training colleges in South Sudan. The study adopted a descriptive cross-sectional survey design and a total of 1953 respondents including the principals, tutors and teacher students from 3 registered and operational teacher training colleges in South Sudan. Stratefied random sampling technique was used to select 321 respondents as the sample size. Pilot study was conducted to asses validity and reliability of the instruments of the study. The study collected primary data using questionnaires and interview guides. The analysis was conducted using descriptive statistics like frequencies and percentages. Besides descriptive statistics, the study used inferential statistics including correlation and regression analysis. The results were presented using Tables and Figures. The study established that humanitarian assistance post conflict intervention measures $(\mathrm{p}<0.05)$ were all significant. Therefore, the study rejected the formulated hypothesis in favour of the alternative hypotheses since their p-values were all less than 0.05 as 5 per cent was considered as the level of significance in the study. Based on regression beta coeffecients and the p-values of the individual variables, the study concluded that humanitarian assistance post conflict intervention measures had positive and significant influence on reconstruction of public teacher training colleges. The study recommended that efforts or reconstructing teachers training college cannot bear fruits unless stakeholders including the humanitarian organizations have been actively involved.
\end{abstract}

Keywords: humanitarian assistance, post conflict intervention measures, reconstruction, public primary teacher training colleges and South Sudan

\section{Introduction}

Most armed combatants around the world deliberately target learners and those teaching them (UN, 2015). Attacks on the educational system of a country encompass a wide range of violations especially those exposing children to risk thereby denying them access to education which is one of the basic needs (Human Rights, 2015). It comprises of attacks on learning facilities and centers, on learners and those teaching them. It also includes the militarization of the above where schools are converted into Military or Police barracks, intimidation of parents, teachers and their children or students; and at times, the forcible recruitment of students/pupils as child soldiers (Human Rights, 2015). These attacks result in children dropping out or absenting from school, reduced/interruptions of learning hours and destruction of school buildings and materials (Lansford, Dodge, Pettit \& Bates, 2016). Examples of countries which have experience such situations includes Nepal, Afghanistan, Iraqi, Rwanda, Liberia and South Sudan.

The infrastructure of in-services teacher training institutes in Iraq is poor with limited capacity of planning, monitoring and managing comprehensive program (Johnson, 2016). UNESCO has been helping the Ministry of Education to create a critical mass of highly qualified teacher trainers. In Afghanistan, The Ministry of Education 2006-2010 strategic plan, the ministry recorded to have facilitated training for those already employed and those yet to be employed who add up to more than 34,000 teachers and deployed more than 137,000 teachers to the schools (Pherali \& Sahar, 2018). 
The major objectives for the strategic plan was to come up with a structure and system that would enable training of about 232,000 teachers for both primary and secondary levels, finance construction and rehabilitation of more than 30 colleges where teachers are trained across the country, Equip and deploy more than 2100 trainers to train teachers in provision of ongoing in-service training besides other support services extension to teachers. Like Pherali and Sahar (2018) noted that the education, political and economy was greatly affected by the chaos during the war.

For effective conflict intervention through using the education system; there is need to focus on training of teachers as the driver of the education system and as the ones who will ensure effective education system that yields positive results. Education means that the youths- who are mostly used to mete out violent acts to opposing groups-would now be engaged in their careers and focus on self-growth and growth of their economy and country (Steenkamp 2009; Boyle 2014).

The case for teacher training is neglected and not prioritized within post-war reconstruction efforts. Most of the efforts and resources goes to primary and secondary schooling, while failing to understand that teachers and learning is one and the same thing. The two aspects complement each other, and to having a functioning education system, the teachers need to be well trained. A study was conducted by the World Bank noted that total lending for the primary, tertiary and secondary education totaled to $43 \%, 12 \%$ and $8 \%$ respectively (Buckland, 2005). In some circumstances, there had been negligible funds going to the entire education sector. For instance, in Iraq, although $\$ 18$ billion were initially allocated for reconstruction, none of these funds were allocated to teachers training colleges in the education sector (Agresto, 2007).

Experts in conflict intervention and reconstruction argue for the case of teacher training in that they can play an important role as far as reconstruction is concerned. In most cases, most of the areas affected by conflicts are largely characterized by short term humanitarian relief and securities (Akil \& Ahmad, 2016). Thus, activities taking a long term horizon in this context are ignored. Such long term activities play an important role in helping individuals as well communities to stand and work (Barakat, 2005). It is important to drift away from a culture that consumption to one where people are encouraged to save and invest including university education.

South Sudan has witnessed conflict for many decades; the crisis in South Sudan has no doubt affected the education sector (Al-Salem, Herricks \& Hotez, 2016). A report by UNESCO Institute for Statistics (UIS) on October 2014 showed that the student-to-teacher ratio is 50:1 with only 44 percent trained teachers. The report further indicated that South Sudan was in need of 79,000 teachers according to UNESCO. UNICEF in its 22nd October 2014 gave a similar report showing South Sudan's education system plagued by critical gaps including lack of trained teachers (40 percent). UNICEF calls for extraordinary efforts in order for South Sudan to realize universal primary school Millennium Development Goal 2 and sequence realization of the United Nations Sustainable Development Goal 4.

\section{Statement of the Problem}

Looking at the cases of Afghanistan, Liberia and Rwanda where these countries experiences lengthy periods of conflicts and wars; the use of education to resolve the issue has been discussed. As such after any conflict, normalcy is usually preferred by all stake holders, however, the effectiveness of such intervention measures by various stakeholders are often faced by hosts of other challenges, that consequently affect effective teacher training and the education system. South Sudan as country has only seven (7) public primary teachers training colleges with only two functioning. This is a dangerous indication that unless the government of South Sudan invest in Teacher training and development, it will not realize its vision 2040 of producing qualified manpower and people who accept and appreciate diversity. The teacher training is critical in any recovery process especially with the situation in South Sudan (Lasater, 2016). This is because if teachers are not well trained, the learners will not be able to get quality education and this will adversely affect the entire education system. Ultimately, the entire process of recovery and reconstruction may not be realized. Therefore, to achieve reconstruction and recovery, a strong fight against literacy need to be a priority, as basic education plays an important role because it produces the majority of workforce (Smidt, 2020). The knowledge, skills and desirable attitude are built right from the basic education by a qualified teacher. Without proper and good basic education, all this values will be lost and illiteracy level will continue to rise thereby creating the need to investigate the influence of humanitarian assistance post conflict intervention measures on reconstruction of public teacher training colleges in South Sudan

\section{Objectives of the Study}

To determine the influence of humanitarian assistance post conflict intervention measures on reconstruction of public teacher training colleges in South Sudan 


\subsection{Review of Related Literature}

\subsubsection{Overview of Global Post Conflict Reconstruction of Teachers Colleges}

In some of the instances, conflict is viewed as a challenge as well as opportunity because post conflict environment can provide an environment for further growth and development of the economies (Buckland 2005; Nicolai 2008). Improving educational policy response in the entire period of conflicts requires an understanding of complex role played by conflicts as far as education system is concerned. Post-conflict reconstruction by use of teacher training programs is an excellent idea since, the program and materials used will often explore life experiences that have shaped the views of the locals (Leach, 2007). The simple deeds of good people can make an enormous difference as well as using the training curriculum to equip the teachers with necessary information and experiences that will help them in handling primary school going children in the learning and healing process after their experiences during the conflict and the war.

In Rwanda, Rubagiza, Umutoni and Kaleeba (2016) elaborated that using well-trained teachers as agents of promoting peace building and social cohesion in schools would help in healing the nation post the genocide era. As such the teachers would be peace actors and agents and working together with other peace actors in different professions work to bring peace in the country.

According to Milton and Barakat (2016) who looked at the catalyst that will drive recovery for the societies that are affected by conflicts and shared that the teacher training program and manual cover these four characteristics, the first being comprehensive, which is aimed at stimulating a wide range of factors within the normal development of children. It does focus on the consequences of trauma and strategies for dealing with those consequences, but also mobilising all possible protective factors that can be provided by a school and benefits not only children at risk, but all children. Secondly, the teacher training program aims at creating mutual support by promoting teachers support to each other during the training phase as well as during their experiences in teaching the children affected by war and helping in reconstructing their lives.

According to the UNHCR report and them working together with INEE and GEC, the refugee children and young people want to be able to go to school and learn, meet new friends in the learning institutions, learn and play and meet teachers; such that they can forget and begin on the healing and reconstructive phase of their lives after the many years of conflict. The learning environment symbolizes a turnaround point from the traumatic experiences of being displaced, loss of property, family and friends and death of the people they knew of during the conflict that has lasted two decades (Loh \& Teo, 2016). UNHCR calls for better coordination throughout the education system, simply through training of teachers who eventually can positively impact the crisis-affected children and youths be able to rebuild their lives again.

These aspects were also highlighted by Hoxha (2013) when covering the conflicts and their impact on social life in Kosovo; which further mentions that the collapse of education system and loss of the educated population through deaths and displacements, resulted in reduced quality of life and increased intensity of work, family life and education difficulties. The challenge in education is lack of physical learning structures like school buildings and materials and poor un-qualified education resources like the case of no well-trained teachers and other resources like books. To be able to rebuild the society, Kosovo needed to invest in provision of basic needs, and key among them is education by providing well-trained teachers, thus looking into the teacher training programs and institutions that will reconstruct the society through educating the young generations.

\subsubsection{Influence of Humanitarian Organization Intervention Measures on Post Conflict Reconstruction of Teacher} Training Colleges

Humanitarian organization intervention measures include funding, capacity building, and infrastructure and food provision. Non-government organizations play a vital role in providing humanitarian assistance to emergency crisis whether man-made or natural emergencies. Afghanistan is one of the countries in Asia that is recovering from twenty five years of crises that destroyed education system. NGO's and UN have played a vital role especially during the period of $1994-2001$ when Taliban banned female participation in the education system (Husting, Kissam \& Intili, 2008). Humanitarian agencies were involved in training teachers and providing educational materials and even by return of a legitimate government in 2002, NGO's have continuously providing assistance to help the country meet educational need. By 2015, the Afghan Ministry of Education estimated 8.3 million students (of which 39 per cent are girls) in primary and secondary unlike in 2001 where it was estimated an enrolment of one million students in primary and secondary schools (UNESCO, 2012).

Humanitarian Assistance has proved to be key player in reconstructions of public teacher training colleges by offering guidelines, ground work on reaching out to locals as well community participation in sustainable peace 
building (Lopez \& Wodon, 2005). The Arusha protocol on refugee return of 1992, mandated that UNHCR to provide shelter and other social amenities for a six-month period for refugee returnees. According to Bruce (2009), the UNHCR donated and spent 183 million dollars in repatriation of refugees back in Rwanda and to their original communes. Some of the other humanitarian organizations that help in post-conflict reconstruction included the The United Nations Assistance Mission for Rwanda (UNAMIR) that took part in the coordination of transport facilities for the internally displaced persons; the IOM and British direct aid (BDA) helped in setting up school programs for the teachers who then would teach the children. The humanitarian agencies embarked in rural shelter program for the returnees by building simple homes to move the returnees from tents to the new homes.

In Sierra Leone, Wurie (2007) shared that the local and international humanitarian organizations, worked together in providing social amenities, key being education and educational materials and resources. There are some developed institutions of teacher training in that vocational/technical institutions help in offering answers to efforts of recovering from conflicts. These institutions helped in develivering relevant skills to most people while supporting those entering institutions of higher learning. According to Grant (2005), the humanitarians also offered free counseling and repatriation for those affected by the war, which would help them cope with the situation in post-conflict Sierra Leone. These humanitarian organizations included locally founded ones, the regional organizations from neighboring West Africa and internationally based ones, that worked together to help re-build the country and its people.

For Rwanda the local and international humanitarian agencies worked together to rebuild the education system, which is now robust and fullfiling (Karareba, Clarke \& O'Donoghue, 2017). For the case of South Sudan, working with humanitarian agencies will be proftable as it will help curb the challenges that have emerged after years of conflict and strife. Toh and Kasturi (2012) mention that some of these challenges include deep socio-economic challenges, internal and external displacement of persons who are in need of humanitarian assistance and furthermore, the explosive and frequent related with violence during the outbreak increase volatility in the country which pose a challenge at developmental as well as the humanitarian organizations.

Teacher training has been seen to play an important role as far transformation of the entire society at large is concerned. According to Toh and Kasturi (2012), teacher training colleges have an important role to play as far as efforts to enhance and built peace is concerned. This helps in enhancing the future of the nation as a whole. South Sudan is made of a population that is largely youthful, about $70 \%$. This has resulted into a situation where youths are restless for the available opportunities that are in limited supply. The role played by teacher training in transforming the economy of the country cannot be overlooked. Efforts should be put in place to ensure that teacher training is utilized so as promote the desired level of resilience as well as peace and sound development of South Sudan as whole (Barakat, Connolly, Hardman \& Sundaram, 2013).

Over forty years, South Sudan has been a brutal experiment in the field of humanitarianism in conflict situations. Humanitarian operations have been critical in the provision of essential medical care, saving lives, documenting the plight of the people of South Sudan, and connecting with the international community in South Sudan. South Sudanese and foreign humanitarians have demonstrated courage, commitment and professionalism, and have achieved a great deal of which they can be proud (Besiou, Stapleton \& Van Wassenhove, 2011).

\subsection{Theoretical Framework}

This study was based on peace-building and conflict prevention theory as postulated by Boutros-Ghali (1992), in “An Agenda for Peace: Preventive Diplomacy, Peace-making and Peace-keeping” (Boutros-Ghali, 1992). This was shortly after the end of the Cold War and at the beginning the era of rapid political and economic liberalization globally. The nature, scale, and proliferation of conflicts was assuming inter/intrastate dimension that however widely undermined development and posed threat to national and regional stability. This had the effect of diverting international attention and the limited resources from more immediate development problems. 'Liberia peace' forms the basis of the approach of peace building and prevention of conflicts around the world and its essence is to ensure that human rights and the law as guiding properties are promoted around the world (Boutros-Ghali, 1992). However, building of peace give priority to establishment of political authority that is not violent so that the past of recovery of the country from post conflict is guided and established and this path includes formation of partnerships with other organizations at a regional level and these help in ensuring that the post conflict efforts of reconstruction are realized. The theory is relevant in this study as it helps out exploit how regions that have faced prolonged conflicts and wars can rebuild, reconstruct and do recovery of their societies. Humanitarian intervention will aide in post-conflict reconstruction. Peacekeeping efforts can be adopted using the 
education system from the basic, elementary and tertiary sectors and change the mind-set of the locals, on top of healing their minds and viewpoints from the experiences they faced during the war.

\subsection{Conceptual Framework}

The conceptual framework of the study is shown in Figure 1. It is used to illustrate the relationship between post conflict intervention and reconstruction of teacher training colleges.

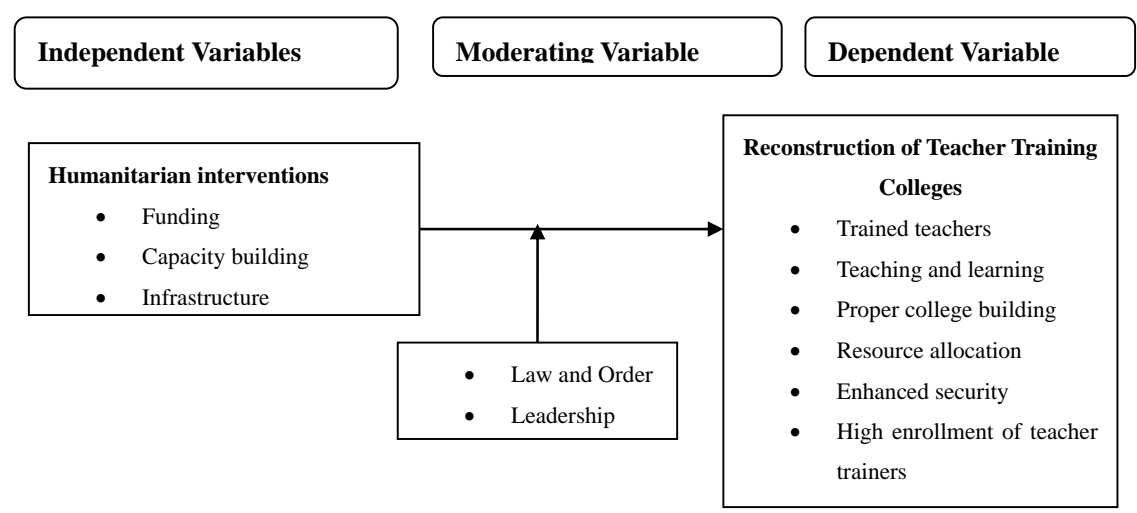

Figure 1. Conceptual framework

\section{Research Methodology}

This study adopted a descriptive cross-sectional survey design; Donald and Pamela (2003) elucidated that a descriptive study aims at determining the what, when and how of a phenomenon studied. The descriptive cross-sectional survey design was ideal in this study as it was able to create room for the respondents to express their views and opinions of the state of teacher training colleges and the impact they have in post conflict era in South Sudan and its efforts in reconstruction and intervention.

This study targeted three teacher training colleges, 3 principals, 150 tutors and 1800 students registered aned 10 key informants (KIs) comprising of local community representatives making the total target population to be 1963 respondents.

Table 1. Target population

\begin{tabular}{ll}
\hline Cagetory & Population \\
\hline Student Teachers & 1800 \\
\hline College Tutors & 150 \\
\hline NTTI Principals & 3 \\
\hline Key Informants & 10 \\
\hline Total & $\mathbf{1 9 6 3}$ \\
\hline
\end{tabular}

The study computed a representative sample of 319 using the formula given by Kothari (2004).

$$
\begin{gathered}
\mathrm{n}=\frac{Z^{2} . N . \sigma^{2} \hat{\mathrm{p}}}{(N-1) e^{2}+Z^{2} \partial^{2} \hat{\mathrm{p}}}=(1.962 * 1963 * 0.52) /(1963-1) 0.052+(1.962 * 0.52)=1885.2652 / \\
(4.905+0.9604)=1875.6612 / 5.8654
\end{gathered}
$$

$\mathrm{n}=319$

Where; $n=$ Size of the sample

$\mathrm{N}=$ Size of the population

$\mathrm{e}=$ Acceptable error given as 0.05 
$\partial^{2} \hat{\mathrm{p}}=$ the standard deviation of the population and given as 0.5 where not known

$\mathrm{Z}=$ standard variation at a confidence level given as 1.96 at $95 \%$ confidence level.

Sample for student teachers=Total number of teacher students/Population Total*Sample Size

$$
\begin{aligned}
& =(1800 * 319) / 1963 \\
= & 293 \text { student teachers }
\end{aligned}
$$

The study then purposively selected the remaining 26 respondents (319-293) as follows: 20 tutors, 1 NTTI principle and 5 Key Informants KIs. Therefore, at the end of the selection process, a total of 319 respopndents were selected and included in the sample of the study as shown in Table 2.

Table 2. Sample size of student teachers

\begin{tabular}{llll}
\hline Category & Population & Sample Proportion & Sample Size \\
\hline Student Teachers & 1800 & Random Sampling & 293 \\
\hline College Tutors & 150 & Purposive & 20 \\
\hline NTTI Principals & 3 & Purposive & 1 \\
\hline Key Informants & 10 & Purposive & 5 \\
\hline Total & $\mathbf{1 9 6 3}$ & & $\mathbf{2 9 3}$ \\
\hline
\end{tabular}

Pilot test was carried out to ascertain data validity and reliability. For testing content validty, efforts were made to ensure that the piloted instruments are fully scrutinized so as to ensure that they were as valid and reliable as possible. Face validity confirmed the coverage of all the areas of investigation by checking the questionnaire and by adopting already tested instruments used by similar studies. The study had a pilot group of 30 respondents who were was used to test the reliability of the research instrument. This study used Cronbach's Alpha (Cronbach, 1951) in the effort to gauge and establish whether the instruments of the study are reliable enough. High Alpha coefficients values are more reliable. The reliability coefficient of 0.70 or greater is considered acceptable reliability (Nunnally \& Bernstein, 1994). According to Mugenda (2008), more than 0.80 indicates a high degree of reliability. The results of the Cronbach Alpha coefficients as computed from these questionnaires are indicated in Table 3.

Table 3. Reliability results

\begin{tabular}{lll}
\hline Variable & Cronbach Alpha Coefficient & Comment \\
\hline Local community intervention measures & 0.920 & Reliable \\
\hline Reconstruction of public teacher training colleges & 0.886 & Reliable \\
\hline
\end{tabular}

Descriptive statistics were used to describe the data of the study, provide simple summaries about the data that was gathered and the measures undertaken. More specifically, the study used frequencies and percentages as the descriptive statistics. The frequencies and percentages were used in carrying out an analysis of the general information of the respondents as well as the independent and the dependent variables of the study.

Regression analysis was used to determine the interaction between the study variables was explored by use of regression analysis. A number of outputs were generated and interpreted in the regression analysis process including the model summary, the ANOVA and the beta coefficient table. The proportionate variability in the dependent variable explained by variability in the independent study variables was modeled and explored with the aid of R square. For ruling out whether the study model was significant in predicting the link between one or more variables, $\mathrm{F}$ test was adopted and used in the study (Mertler \& Reinhart, 2016).

\section{Data Analysis}

\subsection{Instrument Return Rate}

A total of 319 research instruments were administered out of which 293 were student teachers, 20 were college tutors, and 1 NTTI principal among public teacher training colleges in South Sudan and 5 key informants. 304 
research instruments were received back making up a response rate of 95.3 per cent. This response was supported by Mugenda and Mugenda (2003) who noted that response rates of over 70 per cent are deemed to be sufficient for presentation of the results.

\subsubsection{Reconstruction of Public Teacher Training Colleges}

The dependent variable of the study was the reconstruction of public teacher training colleges in South Sudan.

\subsubsection{Reconstruction of Public Teacher Training Colleges' as Shared by Student Teachers}

The results are summarized in Table 4.

Table 4. Institutional rating towards reconstruction of public teacher training colleges' as shared by student teachers

\begin{tabular}{lllllllllll}
\hline & \multicolumn{2}{l}{$\begin{array}{l}\text { Not } \\
\text { Effective }\end{array}$} & & \multicolumn{2}{l}{ Ineffective } & \multicolumn{2}{l}{ Effective } & \multicolumn{2}{l}{$\begin{array}{l}\text { Very } \\
\text { effective }\end{array}$} & \multicolumn{3}{c}{ Total } \\
\hline & $\mathbf{f}$ & $\mathbf{\%}$ & $\mathbf{f}$ & $\mathbf{\%}$ & $\mathbf{f}$ & $\boldsymbol{\%}$ & $\mathbf{F}$ & $\boldsymbol{\%}$ & $\mathbf{f}$ & $\boldsymbol{\%}$ \\
\hline Local NGOs & 33 & 11.8 & 29 & 10.4 & 147 & 52.7 & 70 & 25.1 & $\mathbf{2 7 9}$ & $\mathbf{1 0 0}$ \\
\hline International NGOs & 37 & 13.3 & 32 & 11.5 & 127 & 45.5 & 83 & 29.7 & $\mathbf{2 7 9}$ & $\mathbf{1 0 0}$ \\
\hline
\end{tabular}

Table 4 shows that majority of the respondents (52.7) per cent said that local NGOs are effective as far as reconstruction of public teacher training colleges' was concerned. At the same time, 45.5 per cent of the respondents said that International NGOs play an effective role towards reconstruction of public teacher training colleges' respectively.

\subsubsection{Reconstruction of Public Teacher Training Colleges' as Shared by College Tutors}

The findings on reconstruction of public teacher training colleges as shared by the college tutors are indicated in Table 5.

Table 5. Reconstruction of public teacher training colleges as shared by college tutors

\begin{tabular}{|c|c|c|c|c|c|c|c|c|c|c|}
\hline & \multicolumn{2}{|c|}{$\begin{array}{l}\text { Not } \\
\text { Effective }\end{array}$} & \multicolumn{2}{|c|}{ Ineffective } & \multicolumn{2}{|c|}{ Effective } & \multicolumn{2}{|c|}{$\begin{array}{l}\text { Very } \\
\text { Effective }\end{array}$} & \multicolumn{2}{|c|}{ Total } \\
\hline & $\mathbf{f}$ & $\%$ & f & $\%$ & $\mathbf{f}$ & $\%$ & f & $\%$ & $\mathbf{f}$ & $\%$ \\
\hline Improved quality of trained teachers & 1 & 5 & 1 & 5.0 & 5 & 25.0 & 13 & 65.0 & 20 & 100 \\
\hline Improved/Proper college building & 1 & 5 & 1 & 5.0 & 3 & 15.0 & 15 & 75.0 & 20 & 100 \\
\hline $\begin{array}{l}\text { Improved quality of teaching in } \\
\text { primary school }\end{array}$ & 1 & 5 & 1 & 5.0 & 6 & 30.0 & 12 & 60.0 & 20 & 100 \\
\hline $\begin{array}{l}\text { Increased resource allocation to } \\
\text { colleges }\end{array}$ & 1 & 5 & 2 & 10.0 & 5 & 25.0 & 12 & 60.0 & 20 & 100 \\
\hline Enhanced security around the colleges & 1 & 5 & 1 & 5.0 & 5 & 25.0 & 13 & 65.0 & 20 & 100 \\
\hline High enrollment of teacher trainers & 1 & 5 & 1 & 5.0 & 3 & 15.0 & 15 & 75.0 & 20 & 100 \\
\hline $\begin{array}{l}\text { Availability of teaching and learning } \\
\text { resource }\end{array}$ & 2 & 10 & 2 & 10.0 & 5 & 25.0 & 11 & 55.0 & 20 & 100 \\
\hline
\end{tabular}

Table 5 gives the rating of the respondents on reconstruction of public teacher training colleges. From the results, 65 per cent of the respondents said that there was very effective improvement in quality of trained teachers while 75 percent said that there was very effective improvement in college buildings. The other 60 percent of the respondents said that there was very effective improvement in quality of teaching in primary school, 60 percent indicated very effective increase in resource allocation to colleges, 65 percent indicated very effective enhancement of enhanced security around the colleges, 75 percent said there was very effective increment in 
enrollment of teacher trainers while 55 percent indicated very effective availability of teaching and learning resources.

\subsubsection{Reconstruction of Public Teacher Training Colleges' as Shared by Principal}

The study established some statements on the indicators of re-constructed Public Primary Teachers Training Colleges and the principals were asked to indicate their rating on these statements. A four point scale was used covering effective, not effective, ineffective and very effective. From the findings, the principal indicated that the quality of trained teachers was effective; there was effectiveness in improvement of college building while the resources allocated to the school were not effective.

\subsubsection{Reconstruction of Public Teacher Training Colleges' as per Key Informants}

The KIs noted that although there existed a total of 7 primary teacher colleges in South Sudan, only 3 of these were functional. It was noted that the previous political instability in the country could be attributed to nonfunctional teacher training colleges in South Sudan. This inadequacy of the teacher training colleges could be an indication of why the other stakeholders like the humanitarian agencies was to come in so as to bridge the gap.

The study further established that one of the KI from the ministry of education shared the role of formulation and implementation of education policies including the overall curricula. The KIs went further and disclosed some of the education policies formulated to include training and remuneration of the teachers as well as ensuring the schools were well equipped with infrastructures including the computer labs.

5.1.6 Data Analysis on Humanitarian Assistance Measures and Reconstruction of Public Teacher Training Colleges

The study sought to determine the influence of humanitarian assistance measures on reconstruction of public teacher training colleges in South Sudan.

5.1.7 Perceptions of Tutors and Student Teachers on Humanitarian Assistance Measures

The results are indicated in Table 6.

Table 6. Overall perceptions of student teachers on humanitarian assistance measures

\begin{tabular}{lll}
\hline \multirow{2}{*}{ Item Description } & Frequency & Percentage \\
\cline { 2 - 3 } & $\mathbf{n}$ & $\%$ \\
\hline Fair & 24 & 8.6 \\
\hline Good & 162 & 58.1 \\
\hline Excellent & 93 & 33.3 \\
\hline Total & $\mathbf{2 7 9}$ & $\mathbf{1 0 0}$ \\
\hline
\end{tabular}

From Table 6, majority of the student teachers, 58.1 per cent shared that humanitarian assistance measures had played a good role in reconstruction of public teacher training colleges in South Sudan.

Table 7. Perceptions of tutors on humanitarian assistance measures

\begin{tabular}{lll}
\hline \multirow{2}{*}{ Item Description } & Frequency & Percentage \\
\cline { 2 - 3 } & $\mathbf{n}$ & $\boldsymbol{\%}$ \\
\hline Fair & 4 & 20.0 \\
\hline Good & 14 & 70.0 \\
\hline Excellent & 2 & 10.0 \\
\hline Total & $\mathbf{2 0}$ & $\mathbf{1 0 0}$ \\
\hline
\end{tabular}

From Table 7, majority of the tutors 70.0 per cent indicated that humanitarian assistance measures had played a good role in reconstruction of public teacher training colleges in South Sudan. 
Table 8. Student teachers' perceptions on humanitarian assistance

\begin{tabular}{llllllllllll}
\hline & \multicolumn{2}{c}{ Not Adequate } & \multicolumn{2}{c}{ Adequate } & \multicolumn{2}{c}{ Very adequate } & \multicolumn{2}{c}{ Total } \\
\hline & & $\mathbf{f}$ & $\mathbf{\%}$ & $\mathbf{f}$ & $\mathbf{\%}$ & $\mathbf{F}$ & $\mathbf{\%}$ & $\mathbf{f}$ & $\mathbf{\%}$ \\
\hline $\begin{array}{l}\text { Provision of funding to support the } \\
\text { colleges }\end{array}$ & 68 & 24.4 & 138 & 49.5 & 73 & 26.2 & $\mathbf{2 7 9}$ & $\mathbf{1 0 0}$ \\
\hline $\begin{array}{l}\text { Capacity building of teachers and } \\
\text { principals }\end{array}$ & 60 & 21.5 & 149 & 53.4 & 70 & 25.1 & $\mathbf{2 7 9}$ & $\mathbf{1 0 0}$ \\
\hline $\begin{array}{l}\text { Provision of college Infrastructure to } \\
\text { improve quality }\end{array}$ & 88 & 31.5 & 161 & 57.7 & 30 & 10.8 & $\mathbf{2 7 9}$ & $\mathbf{1 0 0}$ \\
\hline $\begin{array}{l}\text { Provision of medical service supplies to } \\
\text { improve health in the colleges }\end{array}$ & 73 & 26.2 & 143 & 51.3 & 63 & 22.6 & $\mathbf{2 7 9}$ & $\mathbf{1 0 0}$ \\
\hline $\begin{array}{l}\text { Provision of teaching/learning materials } \\
\text { to improve quality in colleges }\end{array}$ & 83 & 29.7 & 151 & 54.1 & 45 & 16.1 & $\mathbf{2 7 9}$ & $\mathbf{1 0 0}$ \\
\hline $\begin{array}{l}\text { Provision of scholarships programme to } \\
\text { support female teachers }\end{array}$ & 96 & 34.4 & 142 & 50.9 & 41 & 14.7 & $\mathbf{2 7 9}$ & $\mathbf{1 0 0}$ \\
\hline
\end{tabular}

Table 8 indicate that 49.5 percent of the respondents said that provision of funding to support the colleges was adequate, 53.4 per cent said that capacity building of teachers and principals was adequate and 57.7 per cent said that there was adequate provision of college infrastructure to improve quality. At the same time, 51.3 per cent of the respondents further said that provision of medical service supplies to improve health in the colleges, 54.1 per cent said that provision of teaching/learning materials to improve quality in colleges was adequate, 50.9 percent that provision of scholarships programme to support female teachers was adequate and 52.3 percent said that there was adequate improvement of public engagement on government policies on teacher education.

The study formulated various statements on humanitarian assistance measures and the tutors were required to respond to these statements. The results are shown in Table 9. $(\mathrm{N}=20)$.

Table 9. Tutors' perceptions on humanitarian assistance

\begin{tabular}{lllllllll}
\hline & \multicolumn{2}{l}{ Not Adequate } & \multicolumn{2}{l}{ Adequate } & \multicolumn{2}{l}{ Very adequate } & \multicolumn{2}{l}{ Total } \\
\hline & $\mathbf{f}$ & $\mathbf{\%}$ & $\mathbf{f}$ & $\mathbf{\%}$ & $\mathbf{f}$ & $\mathbf{\%}$ & $\mathbf{f}$ & $\boldsymbol{\%}$ \\
\hline Provision of funding to support the colleges & 5 & 25.0 & 13 & 65.0 & 2 & 10.0 & 20 & 100 \\
\hline Capacity building of teachers and principals & 6 & 30.0 & 12 & 60.0 & 2 & 10.0 & 20 & 100 \\
\hline $\begin{array}{l}\text { Provision of college Infrastructure to improve } \\
\text { quality }\end{array}$ & 3 & 15.0 & 16 & 80.0 & 1 & 5.0 & 20 & 100 \\
\hline $\begin{array}{l}\text { Provision of medical service supplies } \\
\text { improve health in the colleges }\end{array}$ & 4 & 20.0 & 14 & 70.0 & 2 & 10.0 & 20 & 100 \\
\hline $\begin{array}{l}\text { Provision of teaching/learning materials to } \\
\text { improve quality in colleges }\end{array}$ & 3 & 15.0 & 15 & 75.0 & 2 & 10.0 & 20 & 100 \\
\hline $\begin{array}{l}\text { Provision of scholarships programme } \\
\text { support female teachers }\end{array}$ & 5 & 25.0 & 14 & 70.0 & 1 & 5.0 & 20 & 100 \\
\hline
\end{tabular}

Table 9 shows that 65.0 per cent of the tutors said that the provision of funding to support the colleges was adequate, 60 per cent indicated that capacity building of teachers and principals was adequate, 80 percent indicated that the provision of college infrastructure to improve quality was adequate and 70.0 percent shared that the provision of medical service supplies to improve health in the colleges was adequate. Furthermore, 75.0 percent of the tutors noted that the provision of teaching/learning materials to improve quality in colleges was adequate, 70.0 percent noted that the provision of scholarships programme to support female teachers was adequate, 65.0 percent were of the view that there was adequate improvement in public engagement on government policies on teacher education, 60 percent said that the provision of short refresher courses for teachers was adequate. 
The student teachers were further provided with a number of statements and they were asked to indicate the extent of their agreement. The results are as shown in Table 10. $(\mathrm{N}=279)$.

Table 10. Perceptions of student teachers on humanitarian assistance measures

\begin{tabular}{lllllllll}
\hline & Not Adequate & Adequate & \multicolumn{2}{c}{ Very adequate } & Total \\
\hline & $\mathbf{f}$ & $\mathbf{\%}$ & $\mathbf{f}$ & $\mathbf{\%}$ & $\mathbf{F}$ & $\mathbf{\%}$ & $\mathbf{f}$ & $\mathbf{\%}$ \\
\hline $\begin{array}{l}\text { Humanitarian Assistance is a key player } \\
\text { in reconstructions of public teacher } \\
\text { training colleges by offering guidelines } \\
\text { and community awareness }\end{array}$ & 83 & 29.7 & 140 & 50.2 & 56 & 20.1 & $\mathbf{2 7 9}$ & $\mathbf{1 0 0}$ \\
\hline $\begin{array}{l}\text { NGO are involved in management of the } \\
\text { reconstruction process. }\end{array}$ & 78 & 28.0 & 149 & 53.4 & 52 & 18.6 & $\mathbf{2 7 9}$ & $\mathbf{1 0 0}$ \\
\hline $\begin{array}{l}\text { Involvement of NGO is promoting } \\
\text { accountability }\end{array}$ & 86 & 30.8 & 159 & 57.0 & 34 & 12.2 & $\mathbf{2 7 9}$ & $\mathbf{1 0 0}$ \\
\hline $\begin{array}{l}\text { NGO are involved fundraising for } \\
\text { colleges }\end{array}$ & 89 & 31.9 & 137 & 49.1 & 53 & 19.0 & $\mathbf{2 7 9}$ & $\mathbf{1 0 0}$ \\
\hline $\begin{array}{l}\text { NGO are quality education for all South } \\
\text { Sudanese }\end{array}$ & 69 & 24.7 & 153 & 54.8 & 57 & 20.4 & $\mathbf{2 7 9}$ & $\mathbf{1 0 0}$ \\
\hline $\begin{array}{l}\text { Involvement of NGO is instilling sense } \\
\text { of ownership }\end{array}$ & 76 & 27.2 & 152 & 54.5 & 51 & 18.3 & $\mathbf{2 7 9}$ & $\mathbf{1 0 0}$ \\
\hline $\begin{array}{l}\text { NGOs are involved renovation of college } \\
\text { infrastructure e.g. boreholes }\end{array}$ & 81 & 29.0 & 146 & 52.3 & 52 & 18.6 & $\mathbf{2 7 9}$ & $\mathbf{1 0 0}$ \\
\hline $\begin{array}{l}\text { NGOs are supporting advocacy to } \\
\text { increase the number of colleges by } \\
\text { government }\end{array}$ & 34 & 33.7 & 119 & 42.7 & 66 & 23.7 & $\mathbf{2 7 9}$ & $\mathbf{1 0 0}$ \\
\hline
\end{tabular}

The findings in Table 10 indicate that 50.2 per cent of the student teachers were of the opinion that humanitarian assistance was a key player in reconstructions of public teacher training colleges by offering guidelines and community awareness and 53.4 per cent of the respondents shared that NGOs were involved in management of the reconstruction process. A further 57.0 per cent of the respondents shared that involvement of NGO was promoting accountability, 49.1 per cent said that NGO were involved fundraising for colleges, 54.8 per cent were of the view that NGO were quality education for all South Sudanese and another 54.5 per cent of the respondents said that involvement of NGO was instilling sense of ownership. The study further noted that 52.3 per cent of the respondents shared that NGOs were involved renovation of college infrastructure e.g. boreholes and 42.7 per cent said that NGOs were supporting advocacy to increase the number of colleges by government.

The tutors were provided with a number of statements and they were asked to indicate the extent of their agreement. The results are as shown in Table 11.

Table 11. Perceptions of tutors on humanitarian assistance measures

\begin{tabular}{llllllllll}
\hline & Not Adequate & \multicolumn{2}{l}{ Adequate } & \multicolumn{2}{c}{ Very adequate } & \multicolumn{2}{l}{ Total } \\
\hline & $\mathbf{f}$ & $\mathbf{\%}$ & $\mathbf{f}$ & $\mathbf{\%}$ & $\mathbf{f}$ & $\mathbf{\%}$ & $\mathbf{f}$ & $\mathbf{\%}$ \\
\hline $\begin{array}{l}\text { Humanitarian Assistance is a key player in } \\
\text { reconstructions of public teacher training } \\
\begin{array}{l}\text { colleges by offering guidelines and } \\
\text { community awareness }\end{array}\end{array}$ & 3 & 15.0 & 13 & 65.0 & 4 & 20.0 & $\mathbf{2 0}$ & $\mathbf{1 0 0}$ \\
\hline $\begin{array}{l}\text { NGO are involved in management of the } \\
\text { reconstruction process }\end{array}$ & 2 & 10.0 & 14 & 70.0 & 4 & 20.0 & $\mathbf{2 0}$ & $\mathbf{1 0 0}$ \\
\hline
\end{tabular}




\begin{tabular}{lcccccccc}
\hline $\begin{array}{l}\text { Involvement of NGO is promoting } \\
\text { accountability }\end{array}$ & 2 & 10.0 & 15 & 75.0 & 3 & 15.0 & $\mathbf{2 0}$ & $\mathbf{1 0 0}$ \\
\hline NGO are involved fundraising for colleges & 4 & 20.0 & 13 & 65.0 & 3 & 15.0 & $\mathbf{2 0}$ & $\mathbf{1 0 0}$ \\
\hline $\begin{array}{l}\text { NGO are quality education for all South } \\
\text { Sudanese }\end{array}$ & 4 & 20.0 & 15 & 75.0 & 1 & 5.0 & $\mathbf{2 0}$ & $\mathbf{1 0 0}$ \\
\hline $\begin{array}{l}\text { Involvement of NGO is instilling sense of } \\
\text { ownership }\end{array}$ & 2 & 10.0 & 17 & 85.0 & 1 & 5.0 & $\mathbf{2 0}$ & $\mathbf{1 0 0}$ \\
\hline
\end{tabular}

As indicated in Table 11, it can be shown that 65.0 percent of the tutors noted that the adequacy of humanitarian assistance was a key player in reconstructions of public teacher training colleges by offering guidelines and community awareness, 70.0 per cent said that there was adequacy of the NGOs involved in management of the reconstruction process and 75.0 per cent noted that there was adequacy on involvement of NGO in promoting accountability, 65.0 per cent said that the NGO were involved fundraising for colleges, 75.0 per cent said that the NGO ensured adequate quality education for all South Sudanese, 85.0 per cent said that there was adequacy in involvement of NGO in instilling sense of ownership.

\subsection{Principal Views on Humanitarian Assistance Measures}

The study sampled out one principal who was asked to rate various statements provided under humanitarian assistance measures.

\subsection{Key Informants' Views on Humanitarian Assistance Measures}

The KIs were asked to indicate some of the humanitarian assistance measures that were place for reconstruction of public teacher training colleges. From the findings, one of the KI indicated that the humanitarian organizations organized for capacity building initiatives for the teachers besides provision of funding to bridge the gap due to insufficient funds from the government. Another KIs shared the role of the humanitarian organization in enhancing reconstruction of public teacher training college to include investment in improvement of the infrastructures including the construction of buildings covering the classrooms for learners.

\subsubsection{Regression Results of Humanitarian Assistance Measures and Hypotheses Testing}

The study conducted simple linear regression analysis to determine the interaction between humanitarian assistance measures and reconstruction of public teaching colleges.

\subsubsection{Model Summary of Humanitarian Assistance Measures}

The results of the model summary are shown in Table 12.

Table 12. Model summary of humanitarian assistance measures

\begin{tabular}{lllll}
\hline Model & R & R Square & Adjusted R Square & Std. Error of the Estimate \\
\hline 1 & $.826^{\mathrm{a}}$ & .682 & .681 & .39773 \\
\hline
\end{tabular}

a. Predictors: (Constant), Humanitarian Assistance Measures

From the results in Table 12, the value of adjusted $\mathrm{R}$ square is 0.681 ; which means that 68.1 per cent variation in reconstruction of public teacher training colleges as individually explained by humanitarian assistance measures. Thus, it can be seen that aside from the humanitarian assistance intervention measures, there are other intervention with an influence on reconstruction of public teacher training colleges in South Sudan.

\subsubsection{Analysis of Variance of Humanitarian Assistance Measures}

The study conducted an Analysis of Variance at 5 per cent level of significance and the results are as presented in Table 13. 
Table 13. Analysis of variance on humanitarian assistance measures

\begin{tabular}{llllll}
\hline & Sum of Squares & df & Mean Square & F & Sig. \\
\hline Regression & 101.180 & 1 & 101.180 & 639.615 & $.000^{\mathrm{b}}$ \\
\hline Residual & 47.140 & 298 & .158 & & \\
\hline Total & $\mathbf{1 4 8 . 3 2 0}$ & $\mathbf{2 9 9}$ & & & \\
\hline
\end{tabular}

a. Dependent Variable: Reconstruction of Public Teacher Training Colleges

b. Predictors: (Constant), Humanitarian Assistance Measures

The results in Table 13 indicate that the value of $\mathrm{F}$ calculated as 639.615 while $\mathrm{F}$ critical (at degrees of freedom of 1 and 298) is 3.873. Therefore, the value of F calculated is far above F critical, which is an indication that the overall model used to predict the role of humanitarian assistance intervention measures on reconstruction of public teacher training colleges in South Sudan was significant. The p-value from the model is $0.000(\mathrm{p}<0.05)$ which could be an indication that humanitarian assistance intervention measures had significant effect on reconstruction of public teacher training colleges in South Sudan. The finding is supported by Nishimuko (2009) who reveals that rebuilding peace in Sierra Leone through the education for all policy will need the contribution of the state as well as non-governmental organizations and faith-based organizations in training teachers who then teach the children. When all the parties come together, through building teacher training college's infrastructure and equipping the schools to produce high-quality teachers, then the education quality in the country will improve.

\subsection{Regression Coefficients and Hypotheses Testing}

The study tested the formulated hypothesis through the interpretation of the p-values shown under the significance column in Table 14.

Table 14. Regression coefficients

\begin{tabular}{|c|c|c|c|c|c|}
\hline & \multicolumn{2}{|c|}{ Unstandardized Coefficients } & \multicolumn{2}{|l|}{$\begin{array}{l}\text { Standardized } \\
\text { Coefficients }\end{array}$} & \multirow[b]{2}{*}{ Sig. } \\
\hline & $\overline{\mathbf{B}}$ & Std. Error & Beta & $\mathbf{t}$ & \\
\hline (Constant) & 22.636 & .191 & & 118.494 & .000 \\
\hline $\begin{array}{l}\text { Humanitarian } \\
\text { Measures }\end{array}$ & .264 & .010 & .826 & 25.291 & .000 \\
\hline
\end{tabular}

a. Dependent Variable: Reconstruction of Public Teacher T raining Colleges

From Table 14, the following equation is formulated:

$$
\mathrm{Y}=22.636+.264 \mathrm{X}_{1}
$$

The second objective of the study sought to determine the influence of humanitarian assistance measures on reconstruction of public teacher training colleges in South Sudan. The results showed that when humanitarian assistance measures are held constant, reconstruction of public teacher training colleges in South Sudan would be equivalent to 22.636. A unit change in humanitarian assistance measures while holding other factors constant would lead to 0.264 unit increases in reconstruction of public teacher training colleges in South Sudan

The study was guided by the following hypothesis:

$\mathrm{H}_{1}$ : Humanitarian assistance intervention does not significantly influence reconstruction of public teacher training colleges in South Sudan.

From the results in Table 14, the p-value of humanitarian assistance measure $\mathrm{p}=0.000$ which is less than 0.05 . Thus, the study rejects the hypothesis $\boldsymbol{H}_{\boldsymbol{I}}$ and suggests that humanitarian assistance measures have significant influence on reconstruction of public teacher training colleges in South Sudan. In Sierra Leone Wurie (2007) shared that the local and international humanitarian organizations, worked together in providing social amenities, key being education and educational materials and resources. There are some colleges that have put in place programs to provide answers to efforts for recovery. Through these colleges, one is able to get relevant skills to 
enter the university program. The humanitarians also offered free counseling and repatriation for those affected by the war, which would help them cope with the situation in post-conflict Sierra Leone.

\section{Conclusion and Recommendations}

\subsection{Conclusions}

The objective of the study sought to determine the influence of humanitarian assistance measures on primary teachers' colleges' reconstruction in South Sudan. The hypothesis that on humanitarian assistance intervention did not significantly influence reconstruction of primary teacher colleges' in South Sudan was tested using stepwise regression. Based on the regression results, it was established that humanitarian assistance significantly influenced reconstruction of primary teacher colleges' in South Sudan. There are many challenges that face the education system in South Sudan given its long conflict legacy. It is for this reason that the researcher hopes to add to the academic literature on post-conflict reconstruction by examining the influence of the various post-conflict intervention on teacher college reconstruction in South Sudan.

\subsection{Recommendations From the Study}

Based on the findings, the study made the following recommendations:

- The ministry of general education and instruction in South Sudan should work in close collaboration with all the stakeholders in the field of education as far as reconstruction of training colleges is concerned.

- There is need for the ministry of general education and instruction in South Sudan to immediately renovate the destroyed colleges and construction more across the country to support the need for quality education.

- The efforts or reconstructing teachers training college cannot bear fruits unless stakeholders including the humanitarian organizations have been actively involved.

- Further consideration of Pearson Correlation results imply that humanitarian organizations are playing an important role in reconstruction efforts of teacher training in South Sudan and these efforts should be even be doubled.

- Humanitarian organizations working in South Sudan should increasing funding and capacity building among public teacher training colleges.

\section{References}

Ajieng, M. M. M. (2018). Contributions of diplomatic approaches in resolving conflicts over the river nile water resources among the member states of the nile basin initiative (A Case of South Sudan 2011-2016). Doctoral Dissertation.

Akil, L., \& Ahmad, H. A. (2016). The recent outbreaks and reemergence of poliovirus in war and conflict-affected areas. International Journal of Infectious Diseases, 49, 40-46. https://doi.org/10.1016/j.ijid.2016.05.025

Al-Salem, W., Herricks, J. R., \& Hotez, P. J. (2016). A review of visceral leishmaniasis during the conflict in South Sudan and the consequences for East African countries. Parasites \& Vectors, 9(1), 460. https://doi.org/10.1186/s13071-016-1743-7

Barakat, S. (2009). The failed promise of multi-donor trust funds: aid financing as an impediment to effective state-building in post-conflict contexts. Policy Studies, 30(2), 107-126. https://doi.org/10.1080/01442870902723485

Barakat, S., Connolly, D., Hardman, F., \& Sundaram, V. (2013). The role of basic education in post-conflict recovery. Comparative Education, 49(2), 124-142. https://doi.org/10.1080/03050068.2012.686259

Besiou, M., Stapleton, O., \& Van Wassenhove, L. N. (2011). System dynamics for humanitarian operations. Journal of Humanitarian Logistics and Supply Chain Management, 1(1), 78-103. https://doi.org/10.1108/20426741111122420

Bruce, J. W. (2009). International standards, improvisation and the role of international humanitarian organizations in the return of land in post-conflict Rwanda (pp. 109-131). Uncharted territory: Land, Conflict and Humanitarian Action. https://doi.org/10.3362/9781780440408.007

Buckland, P. (2004). Reshaping the future: Education and post-conflict reconstruction. The World Bank. https://doi.org/10.1596/0-8213-5959-2

Donald, K. K., \& Delno, L. A. (2006). Proposal and thesis writing. Paulines Publications. 
Duggan, S. J. (1996). Education, teacher training and prospects for economic recovery in Cambodia. Comparative Education, 32(3), 361-376. https://doi.org/10.1080/03050069628768

Grant, J. A. (2005). Diamonds, foreign aid and the uncertain prospects for post-conflict reconstruction in Sierra Leone. The Round Table, 94(381), 443-457. https://doi.org/10.1080/00358530500243690

Hoxha, R. (2013). Conflict and its social impact in Kosovo. Academic Journal of Interdisciplinary Studies, 2(11), 87. https://doi.org/10.5901/ajis.2013.v2n11p87

Human Rights Watch. (2015). World Report 2015: Yemen.

Johnson, I. M. (2016). Foreign Intervention and Domestic Initiatives in the Development of Education for Librarianship and Information Management, with Iraq as a Case Study. Doctoral dissertation, Robert Gordon University.

Karareba, G., Clarke, S., \& O'Donoghue, T. (2017). Primary school leadership in post-conflict Rwanda: A narrative Arc. Springer. https://doi.org/10.1007/978-3-319-60264-6

Lansford, J. E., Dodge, K. A., Pettit, G. S., \& Bates, J. E. (2016). A public health perspective on school dropout and adult outcomes: A prospective study of risk and protective factors from age 5 to 27 years. Journal of Adolescent Health, 58(6), 652-658. https://doi.org/10.1016/j.jadohealth.2016.01.014

Lasater, K. (2016). Parent-teacher conflict related to student abilities: the impact on students and the family-school partnership. School Community Journal, 26(2), 237-262.

Leach, F. (2007). Education, conflict and reconciliation: International perspectives. Peter Lang.

Loh, C. Y. R., \& Teo, T. C. (2016). Students' perception of collaborative learning, conflict management and satisfaction in a private educational institution learning environment: an Asian case study. Journal of Education \& Social Policy, 3(3), 72-79.

Lopez, H., \& Wodon, N. (2005). The economic impact of armed conflict in Rwanda. The Hidden Cost of Armed Conflicts. https://doi.org/10.1093/jae/eji021

Middleton, N., \& O'keefe, P. (2006). Politics, history \& problems of humanitarian assistance in Sudan. Review of African Political Economy, 33(109), 543-559. https://doi.org/10.1080/0305624060101067

Milton, S., \& Barakat, S. (2016). Higher education as the catalyst of recovery in conflict-affected societies. Globalisation, Societies and Education, 14(3), 403-421. https://doi.org/10.1080/14767724.2015.1127749

Mugenda, O., \& Mugenda, G. A. (2003). Research methods; qualitative and quantitative. Nairobi: Acts Press.

Nadjaldongar, K. (2008). Lessons learned from the post-conflict reconstruction in Rwanda. Journal of the Development of a Regional Post-Conflict Reconstruction Policy, 1(1), 3-5.

Nicolai, S. (2008). Opportunities for change: Education innovation and reform during and after conflict. Paris: UNESCO.

Pherali, T., \& Sahar, A. (2018). Learning in the chaos: A political economy analysis of education in Afghanistan. Research in Comparative and International Education, 13(2), 239-258. https://doi.org/10.1177/1745499918781882

Rubagiza, J., Umutoni, J., \& Kaleeba, A. (2016). Teachers as agents of change: promoting peacebuilding and social cohesion in schools in Rwanda. Education as Change, 20(3), 202-224. https://doi.org/10.17159/1947-9417/2016/1533

Schauer, S. G., Hill, G. J., Naylor, J. F., April, M. D., Borgman, M., \& Bebarta, V. S. (2018). Emergency department resuscitation of pediatric trauma patients in Iraq and Afghanistan. The American Journal of Emergency Medicine, 36(9), 1540-1544. https://doi.org/10.1016/j.ajem.2018.01.014

Skovdal, M., Emmott, S., \& Maranto, R. (2014). The need for schools in Afghanistan to be declared as zones of peace and neutrality. Child Abuse and Neglect, 38, 170-179. https://doi.org/10.1016/j.chiabu.2014.01.006

Smidt, H. M. (2020). United Nations peacekeeping locally: enabling conflict resolution, reducing communal violence. Journal of Conflict Resolution, 64(2-3), 344-372. https://doi.org/10.1177/0022002719859631

Smith, A. (2005). Education in the twenty-first century: Conflict, reconstruction and reconciliation. Compare: A Journal of Comparative and International Education, 35(4), 373-391. https://doi.org/10.1080/03057920500331397

Toh, K., \& Kasturi, P. (2012). Foreign aid in post-conflict countries: The case of South Sudan. Journal of Third 
World Studies, 29(2), 201-220.

UNESCO. (2010). Education for all global monitoring report 2010: Reaching the marginalized. Paris: UNESCO.

UNICEF. (2015, October 5). Education in Emergencies and Post-Crisis Transition. Retrieved from http://www.unicef.org/education/bege_61685.html

United Nations Mission in South Sudan. (2015). The state of human rights in the protracted conflict in South Sudan.

USAID. (2015). Teacher development and management in South Sudan. Juba.

Wessells, M. (2009). Community reconciliation and post-conflict reconstruction for peace. In Handbook on building cultures of peace (pp. 349-361). Springer, New York, NY. https://doi.org/10.1007/978-0-387-09575-2_24

Wessells, M. G., \& Monteiro, C. (2004). Healing the wounds following protracted conflict in Angola: A community-based approach to assisting war-affected children. Handbook of Culture, Therapy, and Healing, 321-341.

Wessells, M., \& Monteiro, C. (2001). Psychosocial intervention and post-war reconstruction in Angola: Interweaving Western and traditional approaches (pp. 262-275). Peace, Conflict, and Violence: Peace Psychology for the 21st Century.

World Bank. (2010). Country brief: Republic of Congo. January: World bank.

World Bank. (2012). South Sudan - Paving the way for a secure future: 2012 annual report.

Wurie, A. T. (2007). Education reconstruction in post-conflict Sierra Leone. Commonw Educ Partnerships, 2007, 61-64.

\section{Copyrights}

Copyright for this article is retained by the author(s), with first publication rights granted to the journal.

This is an open-access article distributed under the terms and conditions of the Creative Commons Attribution license (http://creativecommons.org/licenses/by/4.0/). 